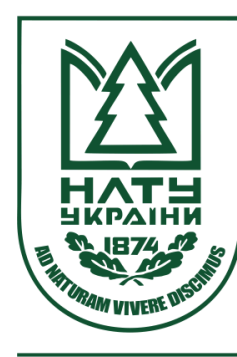

Науковий вісник НЛТУ України Scientific Bulletin of UNFU

http://nv.nltu.edu.ua

https://doi.org/10.15421/40280504

G. V. Denysova

Article received 08.05.2018 p.

Article accepted 31.05.2018 p.

denisova.galyna@gmail.com

удК 712.253

Г. В. Денисова

Національний лісотехнічний університет Украӥни, м. Львів, Украӥна

\title{
КОМПЛЕКСНА ОЦІНКА ДЕКОРАТИВНОСТІ ПАЛАЦОВО-ПАРКОВИХ КОМПЛЕКСІВ ЗАХІДНОГО ЛІСОСТЕПУ
}

\begin{abstract}
На основі аналізу ландшафтно-планувальної структури, стильових особливостей та дендрологічного складу насаджень палацово-паркових комплексів Західного Лісостепу проведено комплексну декоративну та візуально-естетичну оцінку композиційних елементів чотирнадцяти палацово-паркових комплексів. Вони характеризуються відмінностями планувальної структури, стильових особливостей, різним ступенем збереженості та підпорядкуванням. Естетична оцінка охоплює основні елементи паркових композицій та включає одинадцять критеріїв, що дало змогу всебічно охарактеризувати досліджувані об'єкти. За результатами проведеної естетичної оцінки виділено п'ять категорій естетичної привабливості палацово-паркових комплексів Західного Лісостепу, що вирізняються рівнем декоративності та необхідними заходами для підсилення художньої виразності. Результати комплексної естетичної оцінки є основою для пропозицій щодо шляхів регулювання структури насаджень палацово-паркових комплексів Західного Лісостепу, підвищення їх стійкості, довговічності, естетичності, відтворення загальної структури, стилю, пейзажів та елементів історичного ландшафту, формування системи відкритих просторів і розширення видових перспектив.
\end{abstract}

Ключові слова: палацово-паркові комплекси; естетична оцінка; декоративні якості; деревні рослини; композиційні елементи; Західний Лісостеп.

Вступ. Палацово-паркові комплекси Західного Лісостепу мають велику історичну, культурну та природоохоронну цінність. Вони відіграли помітну роль у формуванні художньої виразності краю, стали відображенням естетичних смаків суспільства і є складовою частиною екосистем у тих населених пунктах, де знаходяться. Для палацово-паркових комплексів характерні постійні рекреаційні навантаження та відсутність необхідного догляду, результатом чого $є$ значне зниження їх привабливості та репрезентативності. Руйнівний вплив часу особливо позначився на насадженнях палацовопаркових ансамблів, що здебільшого перебувають у незадовільному стані.

Відсутність належного догляду, а також комплексна дія негативних природних i антропогенних чинників, спричинили погіршення санітарного стану та зниження біологічної стійкості насаджень палацово-паркових комплексів. За таких обставин постає необхідність проведення сучасної оцінки стану парків, що буде основою для подальших пропозицій щодо реконструктивних робіт.

Матеріали та методи дослідження. Проблеми оцінки декоративності насаджень та окремих деревних рослин висвітлено в роботах низки авторів (Halushko 1999; Marno-Kutsa, 2014; Oleksiichenko, 2012; Khoroshykh, 1999). Зокрема В. П. Кучерявий запропонував оцінку на основі використання двох шкал - таксаційнофітоценотичної та емоційної (Kucheriavyi, 2005),

Н. В. Гатальська сформувала критерії дендрологічної оцінки та рівня збереженості ландшафтних об'єктів на прикладі пам'яток садово-паркового мистецтва (Наtalska, 2015).

Для оцінювання декоративності насаджень та інших елементів палацово-паркових комплексів застосовано модернізовану п'ятибальну шкалу на основі шкал оцінки, які запропонували Г. І. Маргайлик, Л. А. Кирильчик та М. Г. Курдюк та зробили власні пропозиції (Kurdiuk, 1982; Marhailyk, Kyrylchyk 1979).

Результати дослідження. Естетичні якості палацово-паркових комплексів оцінювали за комплексом ознак, куди входило 11 критеріїв, що характеризують основні композиційні елементи (табл. 1).

Об'єктами дослідження є 14 палацово-паркових ансамблів, розташованих у населених пунктах Волинської, Івано-Франківської, Львівської, Рівненської, Тернопільської та Хмельницької областей, які характеризуються відмінностями планувальної структури, стильових особливостей, заповідання та підпорядкування, часом створення, ступенем збереженості та розміщені у різних геоботанічних районах Західного Лісостепу.

Такий комплексний метод оцінки декоративності палацово-паркових фітоценозів дав змогу всебічно їх охарактеризувати, отримати уявлення про зовнішній вигляд та внутрішню структуру рослинних угруповань, зафіксувати якісний стан та намітити заходи щодо підсилення їх художньої виразності.

\section{Інформація про авторів:}

Денисова Галина Віталіївна, канд. с.-г. наук, інженер. Email: denisova.galyna@gmail.com

Цитування за ДСту: Денисова Г. В. Комплексна оцінка декоративності палацово-паркових комплексів західного лісостепу. Науковий вісник НЛТУ України. 2018, т. 28, № 5. С. 23-26.

Citation APA: Denysova, G. V. (2018). Ensemble assessment of the decorativeness of palace and park complexes of the Western forest steppe. Scientific Bulletin of UNFU, 28(5), 23-26. https://doi.org/10.15421/40280504 
Табл. 1. Оцінка декоративності насаджень та інших елементів палацово-паркових комплексів Західного Лісостепу

\begin{tabular}{|c|c|c|c|c|c|c|c|c|c|c|c|c|c|c|}
\hline \multirow[b]{2}{*}{$\begin{array}{c}\text { Композиційний } \\
\text { елемент }\end{array}$} & \multicolumn{14}{|c|}{ Оцінка (у балах) за парками } \\
\hline & 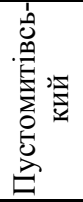 & 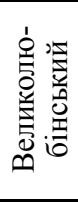 & 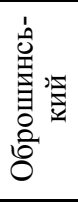 & 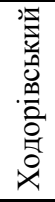 & 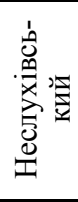 & 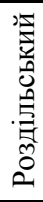 & 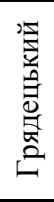 & 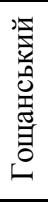 & 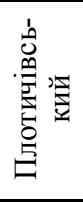 & 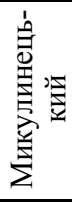 & 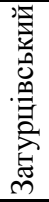 & 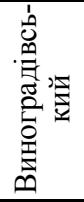 & 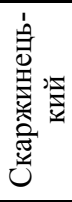 & 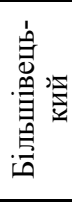 \\
\hline Рельєф & 2 & 3 & 3 & 2 & 5 & 5 & 3 & 2 & 4 & 5 & 3 & 3 & 4 & 4 \\
\hline Водна поверхня & 1 & 1 & 4 & 1 & 4 & 1 & 1 & 2 & 1 & 1 & 2 & 1 & 4 & 1 \\
\hline Архітектоніка насаджень & 3 & 4 & 4 & 3 & 4 & 3 & 3 & 4 & 3 & 4 & 3 & 4 & 3 & 2 \\
\hline Контрастність компонентів & 4 & 4 & 4 & 3 & 5 & 3 & 2 & 3 & 3 & 3 & 3 & 5 & 4 & 3 \\
\hline Конфігурація куртин (ділянок) & 1 & 3 & 3 & 1 & 4 & 4 & 1 & 2 & 3 & 4 & 4 & 4 & 2 & 1 \\
\hline Світлотінь насаджень & 2 & 4 & 4 & 3 & 4 & 3 & 3 & 4 & 3 & 3 & 3 & 5 & 3 & 2 \\
\hline Розміри галявин & 1 & 2 & 4 & 2 & 3 & 4 & 4 & 2 & 3 & 3 & 3 & 4 & 3 & 1 \\
\hline $\begin{array}{l}\text { Конфігурація і мальовничість } \\
\text { галявин }\end{array}$ & 1 & 2 & 2 & 3 & 4 & 4 & 3 & 2 & 3 & 3 & 3 & 4 & 3 & 1 \\
\hline Стан трав'яного вкриття & 4 & 4 & 4 & 2 & 4 & 2 & 3 & 4 & 3 & 3 & 2 & 4 & 3 & 2 \\
\hline Дорожня мережа & 4 & 3 & 4 & 4 & 3 & 3 & 3 & 5 & 4 & 4 & 2 & 2 & 3 & 3 \\
\hline Архітектурні форми і споруди & 1 & 3 & 2 & 3 & 4 & 3 & 1 & 3 & 3 & 4 & 2 & 3 & 1 & 3 \\
\hline Разом & 24 & 33 & 38 & 27 & 44 & 35 & 27 & 33 & 33 & 37 & 30 & 39 & 33 & 23 \\
\hline
\end{tabular}

Основою архітектури пейзажу, що забезпечує створення мальовничих планів і розмежовує простір, виступає рельєф. Чітко виражену рельєфність із приємною контрастністю можна спостерігати в Неслухівському, Роздільському, Микулинецькому та Скаржинецькому палацово-паркових комплексах. Горбистий рельєф (4 бали) характерний для Плотичівського парку, п'ятьом паркам притаманний виражений рельєф (3 бали), а в інших палацово-паркових комплексах рельєф є слабо вираженим (2 бали).

Водойми вважають засобом естетичного збагачення ландшафту, оскільки вони зумовлюють вирішення глибоких перспектив. Вони були невід'ємним елементом території палацово-паркових комплексів, а в багатоьх випадках - композиційним центром парку. Дев'ять палацово-паркових комплексів за цим критерієм отримали 1 бал, оскільки в них водні елементи взагалі відсутні. У Гощанському та Затурцівському парках наявні невеликі заболочені водойми, площа яких не перевищує 1-2 \% (2 бали). Пересихаючі канали із залишками шлюзів Оброшинського палацово-паркового комплексу оцінено 3 балами. Лише в Неслухівському та Скаржинецькому парках композицію ландшафту пожвавлюють мальовничі ставки площею понад 5 \% (4 бали).

Характер паркового пейзажу та його декоративні якості визначають зовнішнім виглядом рослин і архітектурно-художньою розчленованістю насаджень. У сімох палацово-паркових комплексах недостатньо виражені архітектурні компоненти і розчленованість насаджень (3 бали), у шістьох об'єктах виражені архітектурні компоненти і ярусність насаджень (4 бали), а в Більшівецькому парку значну територію займає одноярусний деревостан (2 бали).

Ландшафтно-декоративні якості насаджень значною мірою визначають контрастність, тональність та кольорову гаму компонентів. Серед усіх палацово-паркових комплексів слабо виражену контрастність має Грядецький парк, оскільки участь хвойних дуже мала. Шість палацово-паркових комплексів, де частка хвойних становить до $10 \%$, характеризуються вираженою контрастністю насаджень (3 бали). Тільки в Неслухівському та Виноградівському палацово-парковому комплексах чітко виражена контрастність, де частка хвойних у насадженнях становить 20-50\%, а кольорові компоненти чітко розрізняються.
Покращення контрастності та тональності можна здійснювати шляхом збагачення асортименту видами 3 яскраво забарвленим листям, хвоєю, стовбуром та гіллям.

Конфігурація куртин, що $є$ важливим елементом оцінки декоративності фітоценозів, у Пустомитівському, Ходорівському та Грядецькому парках не виражена (1 бал). Недостатньо мальовнича конфігурація куртин у Великолюбінському, Оброшинському та Плотичівському парках. Інші об'єкти характеризуються мальовничою конфігурацією куртин (4 бали).

Не менш важливим чинником є світлотінь і проглядність насаджень. Відкриті простори повинні бути розміщені так, щоб у палацово-паркових комплексах світло і тінь протягом дня були розподілені доцільно та гармонійно. У Пустомитівському та Більшівецькому парках світлотінь проявляється лише під час низького сонцестояння (2 бали). У половини палацово-паркових комлексів світлотінь середньовиражена (3 бали). У парках, яким присвоєно бали 4 та 5, дотримано рівновагу між освітленим та затіненим простором, світлотінь чітко виражена протягом дня та в різні періоди року, а дерева відображають приємний тіньовий візерунок.

Естетичні якості галявин визначаються їх розмірами та конфігурацією, декоративністю узлісь, наявністю деревних груп та солітерів. У Великолюбінському, Ходорівському та Гощанському палацово-паркових комплексах галявини становлять менше 10 \% площі (2 бали). У чотирьох парках наявність галявин оцінено 3 балами (площа 10-20\%), а галявини площею 20-30\% відзначено у Скаржинецькому, Роздільському, Грядецькому Оброшинському парках. Недостатньо виражена конфігурація галявин у Пустомитівському та Більшівецькому парках. Галявини Великолюбінського, Оброшинського та Гощанського парків оцінено у 2 бали, оскільки вони округлої або квадратної форми зі слабо вираженою конфігурацією узлісся. Галявини з мальовничими контурами і художньо розміщеними солітерами влаштовані в Неслухівському та Роздільському парках. Для решти об'єктів характерні галявини середньої мальовничості без солітерів (3 бали). Підвищити декоративність можна завдяки урізноманітненню узлісь вздовж прогулянкових маршрутів, приховавши монотонність; збагатити пейзаж можна шляхом прорідження насаджень, сформувавши окремі деревні групи. 
Не менш важливим критерієм естетичної оцінки є стан трав'яного вкриття. У Ходорівському, Роздільському та Затурцівському палацово-паркових комплексах газонне вкриття оцінено у 2 бали (вкриття нерівномірне, частка бур'янистих видів у складі фітоценозів - до $10 \%$ ). Трав'яне вкриття у Грядецькому, Плотичівському, Микулинецькому та Скаржинецькому парках рівномірне, частка рудеральних видів - до 5 \%, кольорова гама слабо виражена. В інших парках трав'яне вкриття середньої густоти зі середньо вираженою кольоровою гамою (4 бали).

Дорожня мережа несе функціональне навантаження у переважній більшості парків. У половині палацовопаркових комплексів дорожня мережа вписується у загальну архітектуру парку (4 бали). В'їзні брами акцентують вхід на територію Оброшинського та Роздільського парків.

В усіх досліджуваних палацово-паркових комплекcax наявні палаци, які мають різний ступінь збереженості. Окрім них, на території багатьох об'єктів зафіксовано споруди різного функціонального призначення трансформаторні підстанції, водонапірні вежі, сараї, залишки теплиць, житлові будинки, які дисгармоніюють iз загальною архітектурою комплексів.

Табл. 2. Естетична привабливість палацово-паркових комплексів Західного Лісостепу

\begin{tabular}{|c|c|c|}
\hline $\begin{array}{c}\text { Естетична привабли- } \\
\text { вість насаджень }\end{array}$ & $\begin{array}{c}\text { Градація } \\
\text { балів }\end{array}$ & $\begin{array}{c}\text { Палацово-парковий } \\
\text { комплекс }\end{array}$ \\
\hline Висока & $44-55$ & Неслухівський \\
\hline \multirow{8}{*}{ Середня } & \multirow{8}{*}{$33-43$} & Виноградівський \\
\hline & & Оброшинський \\
\hline & & Микулинецький \\
\hline & & Роздільський \\
\hline & & Великолюбінський \\
\hline & & Гощанський \\
\hline & & Плотичівський \\
\hline & & Скаржинецький \\
\hline \multirow{5}{*}{ Низька } & \multirow{5}{*}{$22-32$} & Затурцівський \\
\hline & & Ходорівський \\
\hline & & Грядецький \\
\hline & & Пустомитівський \\
\hline & & Більшівецький \\
\hline Практично відсутня & менше 21 & - \\
\hline
\end{tabular}

На основі проведеної естетичної оцінки виділено п'ять категорій естетичної привабливості об'єктів (табл. 2). Висока естетична привабливість властива паркам із виразним пластичним рельєфом, природною водною поверхнею, рослинними композиціями, які вирізняються високими декоративними якостями та багатим видовим асортиментом. До цієї категорії належить Нес- лухівський палацово-парковий комплекс, насадження якого повинні бути максимально збережені.

Середню естетичну привабливість зафіксовано у восьми палацово-паркових комплексах із переважно вираженим рельєфом, але нижчими архітектурно-естетичними якостями окремих композиційних елементів.

Низька естетична привабливість властива п'ятьом палацово-парковим комплексам, у яких недостатньо виражені архітектурно-естетичні якості композиційних елементів і відсутні водойми. Вони потребують проведення грунтовних заходів із переформування насаджень та створення композицій.

Висновки. Основними заходами $з$ оптимізації просторової організації території палацово-паркових комплексів $\epsilon$ відтворення загальної структури, стилю, образів, пейзажів та елементів історичного ландшафту, формування системи відкритих просторів і розширення видових перспектив, відновлення втрачених елементів композицій відповідно до часу створення парку, вирішення питань функціонального використання у сучасному середовищі.

\section{Перелік використаних джерел}

Halushko, R. V. (1999). Byomorfolohycheskye pryznaky dlia эkolohoэstetycheskoi otsenky parkovykh soobshchestv. Biulleten Nykytskoho botanycheskoho sada, 81, 23-27. [In Russian].

Hatalska, N. V. (2015). Metodyka vyznachennia dendrolohichnoi tsinnosti ta rivnia zberezhenosti landshaftnykh obiektiv na prykladi parkiv-pamiatok sadovo-parkovoho mystetstva na terytorii Tsentralnoprydniprovskoi vysochynnoi oblasti. Scientific Bulletin of UNFU, 25(6), 36-43. [In Ukrainian].

Khoroshykh, O. H., \& Khoroshykh, O. V. (1999). Shkala kompleksnoi otsinky dekoratyvnykh oznak derevnykh roslyn. Scientific Bulletin of UNFU, 9(9), 167-170. [In Ukrainian].

Kucheriavyi, V. P. (2005). Ozelenennia naselenykh mists. Lviv: Svit. $456 \mathrm{p}$.

Kurdiuk, M. H. (1982). K voprosu otsenky dekoratyvnosty parkovykh nasazhdenyi. Sokhranenye y vosstanovlenye starynnykh parkov, (pp. 65-68). Kyiv: Nauk. Dumka. [In Russian].

Marhailyk, H. Y., \& Kyrylchyk, L. A. (1979). K metodyke otsenky dekoratyvnosty drevesnikh nasazhdenyi. Biul. hlav. botan. sada, 114, 58-60. [In Russian].

Marno-Kutsa, O. Yu., \& Shlapak, V. P. (2014). Kryterii kompleksnoi otsinky suchasnoho stanu ta zberezhenosti istorychnykh parkiv Cherkashchyny. Lisove i sadovo-parkove hospodarstvo, 5. Retrieved from: http://ejournal.studnubip.com/zhurnal-5/ukr/shlapak-v$\mathrm{p} /$. [In Ukrainian].

Oleksiichenko, N. O., \& Hatalska, N. V. (2012). Kryterii kompleksnoi otsinky suchasnoho stanu ta zberezhenosti istorychnykh parkiv na terytorii Tsentralnoprydniprovskoi vysochynnoi oblasti. Lisove i sadovo-parkove hospodarstvo, 2.2 Retrieved from: http://nbuv.gov.ua/j-pdf/licgoc 2012 2 2_10. [In Ukrainian].

\section{КОМПЛЕКСНАЯ ОЦЕНКА ДЕКОРАТИВНОСТИ ДВОРЦОВО-ПАРКОВЫХ КОМПЛЕКСОВ}

ЗАПАДНОЙ ЛЕСОСТЕПИ

На основе анализа ландшафтно-планировочной структуры, стилевых особенностей и дендрологического состава насаждений дворцово-парковых комплексов Западной Лесостепи проведена комплексная декоративная и визуально-эстетическая оценка композиционных элементов четырнадцати дворцово-парковых комплексов. Они характеризуются различиями планировочной структуры, стилевых особенностей, разной степенью сохранности и подчинением. Эстетическая оценка охватывает основные элементы парковых композиций и включает одиннадцать критериев, что позволило всесторонне охарактеризовать исследуемые объекты. По результатам проведенной эстетической оценки выделено пять категорий эстетической привлекательности дворцово-парковых комплексов Западной Лесостепи, отличающиеся уровнем декоративности и необходимыми мерами для усиления художественной выразительности. Результаты комплексной эстетической оценки служат основой для предложений о путях регулирования структуры насаждений дворцово-парковых комплексов Западной Лесостепи, 
повышения их устойчивости, долговечности, эстетичности, воспроизведения общей структуры, стиля, пейзажей и элементов исторического ландшафта, формирования системы открытых пространств и расширения видовых перспектив.

Ключевые слова: дворцово-парковые комплексы; комплексная оценка; декоративные качества; древесные растения; Западная Лесостепь.

\section{G. V. Denysova \\ Ukrainian National Forestry University, Lviv, Ukraine \\ ENSEMBLE ASSESSMENT OF THE DECORATIVENESS OF PALACE AND PARK COMPLEXES OF THE WESTERN FOREST STEPPE}

Constant recreational load and the lack of necessary care for the palace and park complexes lead to significant decline of their attractiveness and representativeness. Therefore, there is a need for the conduction of the reconstructive works, the basis of which should be complex aesthetic assessment of the current state of the palace and park complexes. The research was carried out in fourteen palace and park complexes, which are located in different geobotanical areas of the Western forest steppe. The assessment of the decorativeness of the palace and park complexes was conducted on the modernized five-point scale on the basis of scales of assessment by H. I. Marhailyka, L. A. Kyrylchyka, and M. H. Kurdiuk. We evaluated such as water surface, architectonics of plantations, component contrast, flower-beds configuration, plant lighting, grass cover and road network, constructions. As a result of the conducted aesthetic evaluation, five categories of aesthetic appeal, distinguished by the level of decorative and necessary measures to enhance artistic expression, are distinguished. Nesluhivskyi Park has high aesthetic appeal (44-55 points); Zaturivskyi, Hodorivskyi, Hriadetskyi, Pustomytivskyi and Bilshivetskyi Parks have low aesthetic appeal (22-33 points). Other palace and park complexes have average aesthetic appeal (33-43 points). Palace and park ensembles with practically absent aesthetic appeal (less than 21 points) are not revealed. Accomplished aesthetic assessment is the basis for choosing the reconstructive measures and optimization of the spatial organization of the territory, which will enhance the artistic expressiveness of the palace and park complexes. That will be the restoration of the overall structure, style, landscapes and elements of the historic landscape, the formation of a system of open spaces and the expansion of specific perspectives, the restoration of lost elements of compositions in accordance with the spirit of the time of creation of the park.

Keywords: palace and park complexes; aesthetic assessment; decorative qualities; tree plantings; composite elements; the Western forest steppe. 